\title{
Density Functional Approach: To Study Copper Sulfide Nanoalloy Clusters
}

\author{
Prabhat Ranjan ${ }^{1}$ and Tanmoy Chakraborty ${ }^{2, \star}$ \\ ${ }^{1}$ Department of Mechatronics Engineering, Manipal University Jaipur, Dehmi-Kalan, Jaipur-303007, India \\ ${ }^{2}$ Department of Chemistry, Manipal University Jaipur, Dehmi-Kalan, Jaipur-303007, India \\ *Corresponding author: E-mail: tanmoychem@gmail.com; \\ tanmoy.chakraborty@jaipur.manipal.edu
}

Received: $10-20-2018$

\begin{abstract}
Nano clusters of Copper sulfides (CuS) have paramount importance due to its significant adsorption property and non-toxic behaviour. In this report, nanoalloy clusters of $(\mathrm{CuS})_{n} ;(n=1-8)$ have been theoretically analyzed in terms of Conceptual Density Functional Theory (CDFT) based descriptors, aiming to explore its electronic and other properties. Global DFT based descriptors have been computed for ground state configurations and low-lying isomers of $(\mathrm{CuS})_{\mathrm{n}}$ clusters. Computed HOMO-LUMO gaps, lying in the range of 1.25-3.53 eV, indicate that $(\mathrm{CuS})_{\mathrm{n}}$ clusters may be utilized as renewable energy sources specially in photocatalysis and solar cell applications. A statistical correlation has been established between electronic and photo-catalytic properties of copper-sulfide clusters with their computational counterparts. The close agreement between experimental and computed data supports our analytical approach.
\end{abstract}

Keywords: Density Functional Theory; Copper-Sulfide Cluster; Descriptors; Optoelectronic Property; Regression Analysis

\section{Introduction}

A search of alternative energy resources is one of the most popular topics of the scientific research. Recently, transition metal chalcogenide clusters have gained considerable importance due to their potential applications in the field of energy conversion, storage and optoelectronics. ${ }^{1-6}$ Among them, the compound formed between $\mathrm{Cu}$ and $\mathrm{S}$ is well known semiconducting material that has been extensively used in technological and strategic industries, including thermoelectric cooling materials, solar cells, clean-energy sectors, nonlinear optical materials, lithium ion batteries, gas sensors, nanoscale switches, photocatalysts, supercapacitors, petrochemicals, pharmaceuticals etc. ${ }^{7-21}$ In addition, transition metal clusters particularly $\mathrm{Cu}, \mathrm{Ag}$ and $\mathrm{Au}$ have huge applications in diverse technological domains due to its superior catalytic, magnetic, electronic and optical properties. ${ }^{16,22-24}$ In similar line, advancement of methodologies and characterization techniques have a strong dependence on utilization of different compositions of nanoalloys. ${ }^{16,25-26} \mathrm{~A}$ deep insight of coreshell structure of nano compounds has paramount importance since its properties may be regulated through proper control of other structural and chemical parameters.
In view of regulating power of band gap on electronic properties of any materials, analysis of band gap of semiconductor materials has emerged as a major research domain in science and engineering. Band gap signifies energy difference between the top of the valence band and bottom of the conduction band. The highest occupied energy band represents the valence band and the lowest unoccupied energy band is known as conduction band. ${ }^{27}$ The nature of interaction of light absorbed by semiconducting material can be explained in terms of atomic structure of material. This complex interaction generates the free charge carriers i.e. electrons and holes, which are responsible factors for energy transformation. In order to free an electron from a covalent bond, the light particles, photons, must have to carry at least the energy equal or greater than the band gap of a semiconductor material. ${ }^{28}$ Band gap of semiconductor electrode in the range of $1.63-3.27 \mathrm{eV}(760-380 \mathrm{~nm})$, facilitates generation of free charge carriers in the visible light. It is already reported that zero consumption of energy (no external voltage) for hydrogen production with the use of UV solar light can be achieved utilizing TiO2 electrodes in Photo Electro Chemical (PEC) cells sunlight-absorbing semiconductor. ${ }^{29} \mathrm{~A}$ large number of theoretical 
and experimental studies based on catalytic materials for water splitting reaction have also been reported, which generate the new results on bulk semiconductor photocatalysts. ${ }^{30}$ Recently, heterogeneous nanomaterials have also confirmed their highest catalytic performance to be developed as novel semiconductor electrodes in PEC cells. ${ }^{31}$

Copper Sulfides (CuS) have become popular in view of their three major properties namely high adsorption, non-toxic behaviour and the most importantly abundance in nature (i.e cheap material). ${ }^{32}$ By customizing the structure and concentration ratio of copper or sulfide, their respective energy band gap can be regulated. A number of reported data reveals the band gap of stoichiometric composition of copper sulfides, chalcocite $\left(\mathrm{Cu}_{2} \mathrm{~S}\right)$, djurleite $\left(\mathrm{Cu}_{1.97} \mathrm{~S}\right)$, digenite $\left(\mathrm{Cu}_{1.8} \mathrm{~S}\right)$ and covellite $(\mathrm{CuS})$ as 1.22 , $1.40,1.55$ and $2.0 \mathrm{eV}$ respectively. ${ }^{33-36}$ Keeping in view the data, it can be assumed that there is inverse relationship energy between band gap and the number of copper atoms in the clusters. The energy band gap for copper sulfide clusters, ranging from $1.2 \mathrm{eV}$ to $2.5 \mathrm{eV}$, supports behavior of cluster as a leading p-type semiconducting material and suitable candidate for solar cells, nonvolatile memory devices, optoelectronics and non-liner optical devices. ${ }^{1,8,11-13,37-38}$ Recently, Li et al. have reported copper and sulfur doped copper clusters, describing the growth pattern of the $\mathrm{Cu}_{\mathrm{n}-1} \mathrm{~S}$ clusters. ${ }^{39}$ In this work, authors have computed the optimized geometry, HOMO-LUMO gap, molecular orbital energy and density of states of $\mathrm{Cu}_{\mathrm{n}-1} \mathrm{~S}$ clusters. The computed HOMO-LUMO gaps are in the range of $1.42-2.96 \mathrm{eV}$, which make $\mathrm{Cu}_{\mathrm{n}} \mathrm{S}$ clusters suitable for renewable energy sources. The cluster $\mathrm{Cu}_{2} \mathrm{~S}$ (Planar structure, $\mathrm{C}_{2 \mathrm{v}}$ ) has been identified as the most stable geometry with the highest HOMO-LUMO gap (2.96 eV). Sánchez et al. have also reported the structure and electronic properties of $(\mathrm{CuS})_{\mathrm{N}}$ clusters $(\mathrm{N}=1-6)$ in terms of DFT calculations. ${ }^{15}$ The authors also claimed the renewable energy property of the clusters on basis of computed HOMO-LUMO gaps, ranging between 1.3-3.3 eV. Due to high theoretical capacity, flat discharge curve and very good specific charge capacities, copper sulfide has been proven an excellent cathode material for lithium ion batteries. $^{40-42}$ The inclusion of copper nanocrystals into sulfur electrode helps to intensify the cyclability of Li-S battery by alteration of sulfur to more electrochemically stable $\mathrm{CuS}^{43,44}$ All these properties make copper sulfide a suitable candidate for capacity-contributing conductive filler for the sulfur electrode. ${ }^{45}$ Xie et al. have studied the compositional transformations of CuS nanocrystals when exposed to divalent cations, as $\mathrm{Cd}^{2+}$ and $\mathrm{Hg}^{2+}$ at room temperature in organic solvents. ${ }^{46}$ The authors claimed that the feature and mechanism of this analysis may be helpful in study of nanoscale chemical transformations. Karikalan et al. have studied the sonochemical route to synthesis of sulfur doped reduced graphene oxide and $\mathrm{CuS}$ nanocomposite. ${ }^{47}$ The authors have validated the practicability of the developed glucose sensor in real biological samples.
Selvi et al. have synthesized CuS and CdS nanoparticles capped with CTAB using hydrothermal technique. ${ }^{48}$ The result obtained from this study indicate that $\mathrm{CuS}$ and $\mathrm{CdS}$ with band gap of $1.8 \mathrm{eV}$ and $2.3 \mathrm{eV}$ respectively can be suitable for optoelectronic devices and photovoltaic applications. However, it is felt that deep insight in terms of experimental and theoretical analysis is required to further explore the intrinsic properties of these clusters. ${ }^{49-50}$

Density Functional Theory has gained importance due its computational friendly behavior. DFT is a widely accepted method to study the electronic structure of many-body systems. In the domain of material science research, particularly in super conductivity of metal based alloys, ${ }^{51}$ magnetic properties of nano-alloy clusters, ${ }^{52}$ quantum fluid dynamics, molecular dynamics, ${ }^{53}$ nuclear physics ${ }^{54}$ DFT has become popular technique. The study of density functional theory spreads over three major areas viz. theoretical, conceptual, and computational. ${ }^{55-57} \mathrm{Con}$ ceptual density functional theory is recognized as an important tool to study the chemical reactivity of materials. ${ }^{58-60}$ The conceptual density functional theory is highlighted following Parr's dictum "Accurate calculation is not synonymous with useful interpretation. To calculate a molecule is not to understand it". ${ }^{61}$ We have been extensively applying conceptual density functional based global and local descriptors to study physico-chemical properties of nano-engineering materials and drug designing process. ${ }^{62-68}$

Computational study invoking DFT on CuS clusters is very limited. In this venture, we have analyzed electronic and photo-catalytic properties of $(\mathrm{CuS})_{\mathrm{n}}$ nanoalloy clusters as a function of their size; $n=1-8$. Conceptual DFT based descriptors namely electronegativity, hardness, HOMO-LUMO gap, softness, electrophilicity index and dipole moment have been computed to correlate physico-chemical properties of the compounds. It also helps to analyze the stability and the semiconducting behavior of the clusters. A comparative analysis has been done between available experimental reports with our computed data. Considering paucity of DFT based study on these compounds, it is assumed that our analysis may help to bring a new insight in the domain of renewable energy sources.

\section{Computational Details}

In this report, we have done computational analysis of the nanoalloy clusters of $(\mathrm{CuS})_{n}(n=1-8)$ in terms of Density Functional Theory based global descriptors. 3d modeling and structural optimization of all the compounds have been performed using Gaussian $03^{69}$ within Density Functional Theory framework. Hybrid functional Becke, three parameter, Lee-Yang-Parr (B3LYP) exchange correlation with basis set LanL2dz has been adopted for geometry optimization. No restriction is imposed on mo- 
lecular spin during energy minimization process. Z-axis is considered as spin polarization axis. In order to ensure orthogonalization on the (frozen) Core Orbitals (COs), Symmetrized Fragment Orbitals (SFOs) have been combined with auxiliary Core Functions (CFs).

Invoking Koopmans' approximation, ${ }^{58}$ we have computed Ionization Energy (I) and Electron Affinity (A) for all the nano alloys using the following ansatz-

$$
\begin{aligned}
& \mathrm{I}=-\varepsilon_{\text {HOMO }} \\
& \mathrm{A}=-\varepsilon_{\text {LUMO }}
\end{aligned}
$$

Thereafter, using I and A, the conceptual DFT based global molecular descriptors viz. electronegativity $(\chi)$, global hardness $(\eta)$, molecular softness $(S)$ and electrophilicity index $(\omega)$ have been computed. The equations used for such calculations are as follows-

$$
\chi=-\mu=\frac{I+A}{2}
$$

Where, $\mu$ represents the chemical potential of the system.

$$
\begin{aligned}
& \eta=\frac{I-A}{2} \\
& S=\frac{1}{2 \eta} \\
& \omega=\frac{\mu^{2}}{2 \eta}
\end{aligned}
$$

\section{Results and Discussion}

\subsection{Equilibrium Geometries}

In this section the structural aspects of low lying isomers of $(\mathrm{CuS})_{n}(\mathrm{n}=1-8)$, which were obtained during the search of ground state geometries, are discussed. The results for the most stable structure and low-lying structures of CuS clusters are presented in Figure-1. The linear structure is obtained for diatomic $\mathrm{CuS}$ cluster. The structure with $\mathrm{C}_{\infty} \mathrm{v}$ symmetry has a bond length of $2.18 \AA$, which is nicely correlated with the data reported by Sánchez et al. ${ }^{15}$

We have listed five low-lying isomers for $n=2$. It is observed that the optimized ground state geometry of $(\mathrm{CuS})_{2}, 2$-a, with $\mathrm{D}_{2 \mathrm{~h}}$ symmetry is energetically more favorable than the other isomers, because rhombus structure of this cluster forces $\mathrm{Cu}-\mathrm{Cu}$ bond distances to be shorter. In the lowest energy structure of $(\mathrm{CuS})_{2}$, the bond length of $\mathrm{Cu}-\mathrm{Cu}$ and $\mathrm{CuS}$ is 2.30 and $2.12 \AA$ respectively. The structure 2-b and 2-c with symmetry of $\mathrm{C}_{2}$ and $\mathrm{C}_{1}$ respectively, have an angle of $109.47^{\circ}$. The structure 2-b is energetically higher than the lowest energy structure of 2 -a by $0.3 \mathrm{eV}$ but at the same time it is lower in energy than structure 2-c. Magnitude of energy difference between the structures $2-\mathrm{d}$ and 2 -e is very small.

Six low lying isomers of $(\mathrm{CuS})_{3}$ clusters are identified. The cluster $3-\mathrm{a}$, having a $3 \mathrm{D}$ geometry and symmetry $\mathrm{C}_{1}$, is more stable than the planar structures. The 3-a cluster arises from the coordination of one copper and one sulfur atom from top and bottom of rectangular cluster. The bond lengths of $\mathrm{Cu}-\mathrm{Cu}, \mathrm{Cu}-\mathrm{S}$ and $\mathrm{S}-\mathrm{S}$ in 3-a cluster are 2.31, 2.19 and $2.06 \AA$ respectively. The second most low lying isomer is $3-\mathrm{b}$ which is $0.82 \mathrm{eV}$ lower than the most stable structure of 3-a. Four more low-lying isomers, namely 3-c, 3-d, 3-e and 3-f, are also found in the range of $2.77 \mathrm{eV}$. A close agreement of energy value is observed for the structures 3-c and 3-d. Cluster 3-d is energetically higher than $3-\mathrm{c}$ by $0.16 \mathrm{eV}$.

A number of low-lying isomers are found out for the $(\mathrm{CuS})_{4}$ cluster. Our computed result indicates that first three low-lying three dimensional structures (4-a, 4-b and $4-c)$ are lower in energy than the planar structure. The most stable structure 4 -a has a triangle in between the cluster, surrounded by sulfur atoms, forming triangle with copper. The bond lengths of $\mathrm{Cu}-\mathrm{Cu}, \mathrm{Cu}-\mathrm{S}$ and S-S in cluster 4 -a are $2.35,2.27$ and $1.94 \AA$ respectively. The clusters 4 - $\mathrm{d}$ and 4 -e are found to be very close in energy and 4-e is only $0.08 \mathrm{eV}$ higher than $4-\mathrm{d}$. The most stable structure (4-a), with C1 symmetry and 3D geometry, is energetically lower than the planar structure (4-d) by $1.00 \mathrm{eV}$. The planar structures of three isomers (4-d, 4-f and 4-g), formed by placing $\mathrm{Cu}$ atoms on all sites of structures, are within an energy range of $2.72 \mathrm{eV}$.

It is observed that for cluster $(\mathrm{CuS})_{5}$, structure 5 -a, having symmetry group $\mathrm{C}_{1}$, is the most stable isomer. The structure corresponds to an interaction of two four atoms cluster of $\mathrm{Cu}_{2} \mathrm{~S}_{2}$ connected back to back, while one sulfur and copper atom are coordinated to an edge of the same $\mathrm{Cu}_{2} \mathrm{~S}_{2}$ cluster. In the structure 5-a, the bond lengths between $\mathrm{Cu}-\mathrm{Cu}, \mathrm{Cu}-\mathrm{S}$ and $\mathrm{S}-\mathrm{S}$ are 2.25, 2.17 and $1.89 \AA$ respectively. The second most stable isomer, $5-\mathrm{b}$ is found to be $1.02 \mathrm{eV}$ higher in energy than 5 -a. Four more low-lying structures are found in the range of $4.61 \mathrm{eV}$. The structure 5-e is also formed through the interaction of two $\mathrm{Cu}_{2} \mathrm{~S}_{2}$ clusters connected back to back, though $\mathrm{Cu}$ and $\mathrm{S}$ atoms arranged in a different way compared to structure 5 -a. The isomer 5 -e is $4.61 \mathrm{eV}$ higher in energy than the most stable structure 5-a.

Five low-lying isomers are identified for $(\mathrm{CuS})_{6}$ cluster. The cluster 6-a with symmetry $\mathrm{C}_{1}$ is found to be the most stable structure. It arises from the coordination of four sulfur atoms on the edge forming triangles with six copper atoms, while remaining two sulfur atoms interacting with the face of the cluster. The bond lengths between $\mathrm{Cu}-\mathrm{Cu}, \mathrm{Cu}-\mathrm{S}$ and $\mathrm{S}-\mathrm{S}$ in the lowest energy structure of $(\mathrm{CuS})_{6}$ are 2.28, 2.19 and $2.13 \AA$ respectively. The second most stable structure 6-b is a star like structure with interaction of two six atoms double layered cluster. The second and third most stable structures, 6-b and 6-c are energeti- 


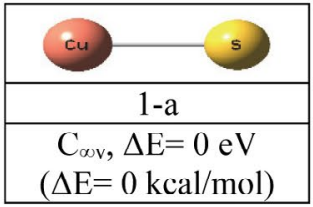

\begin{tabular}{|c|c|c|c|c|}
\hline & & \\
\hline $2-\mathrm{a}$ & $2-\mathrm{b}$ & $2-\mathrm{c}$ & $2-\mathrm{d}$ & \\
\hline $\begin{array}{c}\mathrm{D}_{2 \mathrm{~h}}, \Delta \mathrm{E}=0 \mathrm{eV} \\
(\Delta \mathrm{E}=0 \mathrm{kcal} / \mathrm{mol})\end{array}$ & $\begin{array}{c}\mathrm{C}_{2}, \Delta \mathrm{E}=0.3 \mathrm{eV} \\
(\Delta \mathrm{E}=6.91 \mathrm{kcal} / \mathrm{mol})\end{array}$ & $\begin{array}{c}\mathrm{C}_{\mathrm{l}}, \Delta \mathrm{E}=0.5 \mathrm{eV} \\
(\Delta \mathrm{E}=11.53 \mathrm{kcal} / \mathrm{mol})\end{array}$ & $\begin{array}{c}\mathrm{C}_{\mathrm{s}}, \Delta \mathrm{E}=0.8 \mathrm{eV} \\
(\Delta \mathrm{E}=18.44 \mathrm{kcal} / \mathrm{mol})\end{array}$ & $\begin{array}{c}\mathrm{C}_{\mathrm{s}}, \Delta \mathrm{E}=0.82 \mathrm{eV} \\
(\Delta \mathrm{E}=18.91 \mathrm{kcal} / \mathrm{mol})\end{array}$ \\
\hline
\end{tabular}

\begin{tabular}{|c|c|c|c|c|c|}
\hline (9) & $\theta$ & $\rho$ & $\Leftrightarrow$ & & $\rho$ \\
\hline $3-a$ & 3-b & 3-c & 3-d & $3-\mathrm{e}$ & 3-f \\
\hline $\begin{array}{c}\mathrm{C}_{1}, \Delta \mathrm{E}=0 \mathrm{eV} \\
(\Delta \mathrm{E}=0 \mathrm{kcal} / \mathrm{mol})\end{array}$ & $\begin{array}{c}\mathrm{C}_{\mathrm{S}}, \Delta \mathrm{E}=0.81 \mathrm{eV} \\
(\Delta \mathrm{E}=18.67 \mathrm{kcal} / \mathrm{mol})\end{array}$ & $\begin{array}{c}\mathrm{C}_{\mathrm{s}}, \Delta \mathrm{E}=1.36 \mathrm{eV} \\
(\Delta \mathrm{E}=31.36 \mathrm{kcal} / \mathrm{mol})\end{array}$ & $\begin{array}{c}\mathrm{C}_{1}, \Delta \mathrm{E}=1.52 \mathrm{eV} \\
(\Delta \mathrm{E}=35.05 \mathrm{kcal} / \mathrm{mol})\end{array}$ & $\begin{array}{c}\mathrm{C}_{1}, \Delta \mathrm{E}=2.01 \mathrm{eV} \\
(\Delta \mathrm{E}=46.35 \mathrm{kcal} / \mathrm{mol})\end{array}$ & $\begin{array}{c}\mathrm{C}_{2 \mathrm{v}}, \Delta \mathrm{E}=2.77 \mathrm{eV} \\
(\Delta \mathrm{E}=63.87 \mathrm{kcal} / \mathrm{mol})\end{array}$ \\
\hline
\end{tabular}

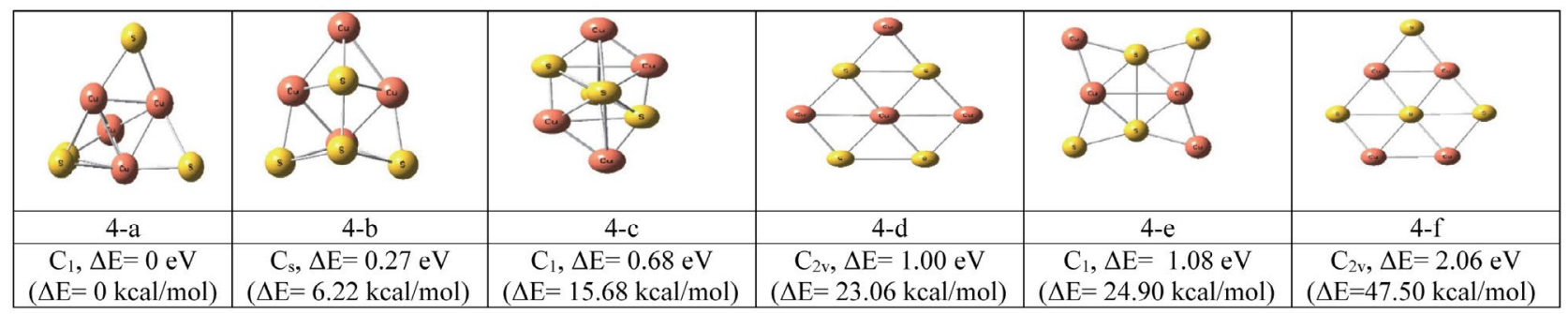

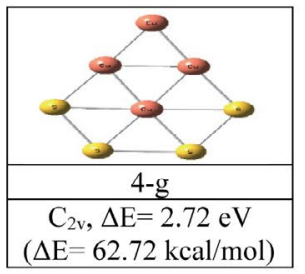

\begin{tabular}{|c|c|c|c|c|}
\hline 5-a & 5-b & $5-\mathrm{c}$ & 5-d & 5-e \\
\hline $\begin{array}{c}\mathrm{C}_{1}, \Delta \mathrm{E}=0 \mathrm{eV} \\
(\Delta \mathrm{E}=0 \mathrm{kcal} / \mathrm{mol})\end{array}$ & $\begin{array}{c}\mathrm{C}_{1}, \Delta \mathrm{E}=1.02 \mathrm{eV} \\
(\Delta \mathrm{E}=23.52 \mathrm{kcal} / \mathrm{mol})\end{array}$ & $\begin{array}{c}\mathrm{C}_{\mathrm{s}}, \Delta \mathrm{E}=2.70 \mathrm{eV} \\
(\Delta \mathrm{E}=62.26 \mathrm{kcal} / \mathrm{mol})\end{array}$ & $\begin{array}{c}\mathrm{C}_{1}, \Delta \mathrm{E}=3.8 \mathrm{eV} \\
(\Delta \mathrm{E}=87.62 \mathrm{kcal} / \mathrm{mol})\end{array}$ & $\begin{array}{c}\mathrm{C}_{1}, \Delta \mathrm{E}=4.61 \mathrm{eV} \\
(\Delta \mathrm{E}=106.30 \mathrm{kcal} / \mathrm{mol})\end{array}$ \\
\hline
\end{tabular}

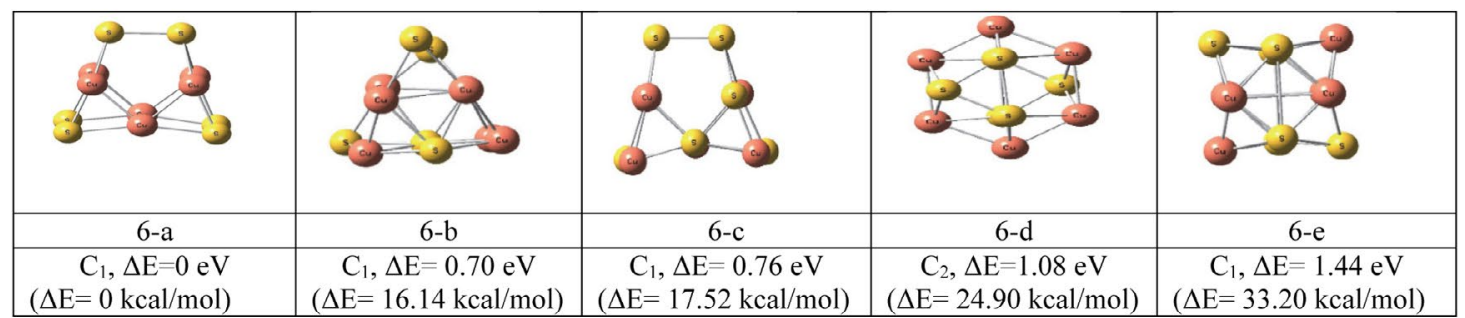

Figure 1.

Ranjan and Chakraborty et al.: Density Functional Approach: To Study Copper Sulfide ... 

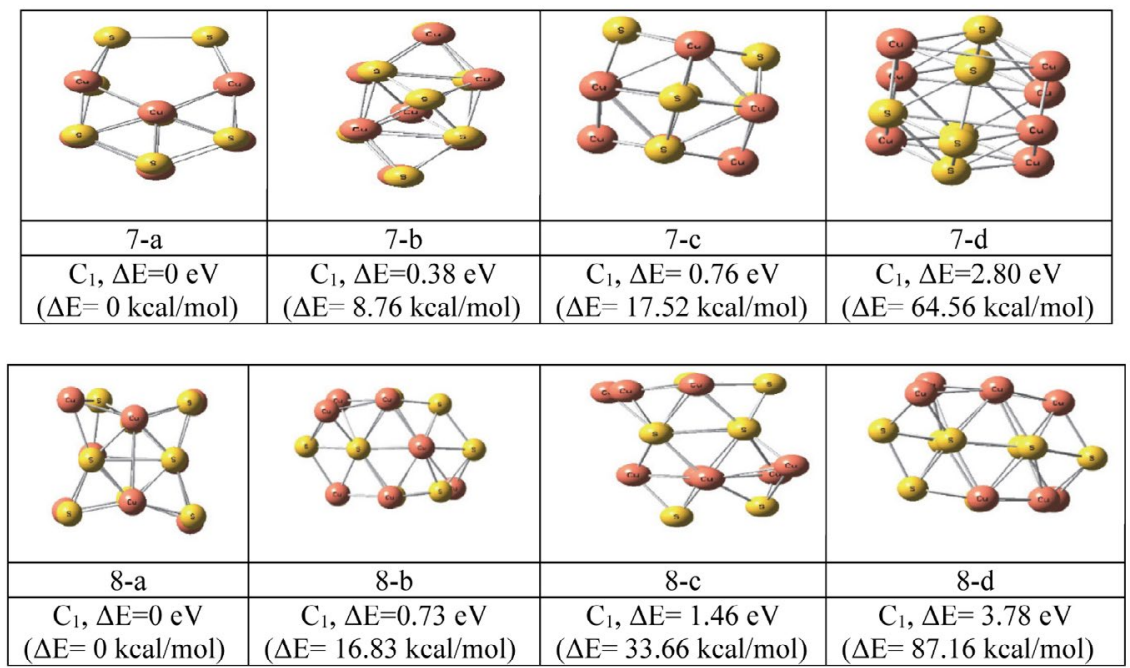

Figure 1. Structures of low-energy isomers for $(\mathrm{CuS})_{n}$ clusters $(n=1-8)$. Relative energies and symmetry group are given at B3LYP/ LanL2dz level. $\mathrm{Red}$ spheres represent $\mathrm{Cu}$ atoms and yellow ones represent $\mathrm{S}$ atoms.

cally less stable than 6 -a by 0.70 and $0.76 \mathrm{eV}$ respectively.

Among four low-lying isomers of $(\mathrm{CuS})_{7}$ cluster, the structure 7 -a, having symmetry group $C_{1}$, is the most stable cluster. In the structure 7-a, the bond lengths between $\mathrm{Cu}-\mathrm{Cu}, \mathrm{Cu}-\mathrm{S}$ and S-S are 2.24, 2.14 and $2.13 \AA$ A respectively. The second most stable cluster is energetically higher than 7 -a by $0.38 \mathrm{eV}$. Two more low-lying isomers are found to be within $2.80 \mathrm{eV}$ energy range.

Four low-lying isomers, within the range of $3.78 \mathrm{eV}$, are identified for $(\mathrm{CuS})_{8}$ cluster. The 8 -a structure arises from the coordination of double layer $\mathrm{Cu}_{4} \mathrm{~S}_{4}, \mathrm{C}_{1}$ cluster. The bond lengths between $\mathrm{Cu}-\mathrm{Cu}, \mathrm{Cu}-\mathrm{S}$ and $\mathrm{S}-\mathrm{S}$ in the lowest energy structure of $(\mathrm{CuS})_{8}$ are $2.32,2.29$ and $2.15 \AA$ respectively. The second and third most stable isomers, 8 -b and 8 -c are 0.73 and $1.46 \mathrm{eV}$ less stable than 8 -a, respectively. Other isomers are also found but they are of high energy. The computed bond lengths between $\mathrm{Cu}-\mathrm{Cu}, \mathrm{Cu}-\mathrm{S}$ and S-S of lowest energy structure reveals that the bond lengths in $(\mathrm{CuS}) \mathrm{n}$ clusters follow the order $\mathrm{Cu}-\mathrm{Cu}>\mathrm{Cu}-\mathrm{S}$ $>$ S-S. The calculated bond lengths are consistent with the results obtained by Sanchez et al. [15].

\section{2. The HOMO-LUMO Gaps and DFT Based Global Descriptors}

In this paper, we have reported computational analysis invoking electronic structure theory of copper sulfide nanoalloy clusters. The orbital energies as HOMO (Highest Occupied Molecular Orbital)-LUMO (Lowest Unoccupied Molecular Orbital) gap along with computed DFT based global descriptors for copper sulfide nanoalloy clusters have been presented in the Table- 1 . The molecular dipole moment of the compounds in Debye unit is also reported in the Table-1. Our computed HOMO-LUMO gap for the copper sulfide clusters $(\mathrm{CuS})_{\mathrm{n}}, \mathrm{n}=1-8$ has range from 1.25 to $3.53 \mathrm{eV}$. This is in close agreement with the desirable band gap of semiconducting nano materials, suitable for photo-catalytic processes and renewable energy application. ${ }^{15,32,39}$ The HOMO-LUMO gap of these clusters is running parallel with the reported data. ${ }^{15}$ From Table-1, a direct relationship is revealed between HOMO-LUMO gaps of the nano-clusters and their evaluated global hardness. Frontier orbital energy gap and computed global hardness run hand in hand. This trend is expected considering experimental analysis. The molecule possessing the highest HOMO-LUMO gap will be the least prone to response against any external perturbation. It validates that clusters, having larger HOMO-LUMO gap, require significant amount of energy to promote electrons from the occupied to the unoccupied molecular orbitals. Our computed data reveals that $(\mathrm{CuS})_{3}$ restricts itself to exhibit any response against the external perturbation whereas $(\mathrm{CuS})_{4}$ exhibits the maximum reactivity under similar condition. In absence of quantitative benchmark pertaining to optical properties of aforesaid clusters, it is tacitly assumed that there must be a direct qualitative relationship between optical properties (specifically photo-catalytic) of $\mathrm{CuS}$ nano-clusters with their computed HOMO-LUMO gap. The assumption has the basis that optical properties of materials are governed by flow of electrons within the systems, which in turn depends on the energy difference between valence and conduction band. A linear relationship between HOMO-LUMO gap with the difference in the energy of valence-conduction band is already reported..$^{70}$ In view of that, it can be concluded that optical properties of the nano-clusters will be enhanced with an increase in their hardness values. Similarly, the softness data exhibits an inverse relationship towards the experimental optical properties. Table- 1 also signifies that computed electronegativity and electrophilicity index have an 
inverse relationship with HOMO-LUMO gap of CuS nano-clusters. Parr et al. have already reported that electrophilicity index measures the energy lowering of a ligand due to maximal electron flow between donor and acceptor and it depends on conjoint action of ionization potential and electron affinity. ${ }^{71}$ The linear correlation between $\mathrm{HO}$ MO-LUMO gap along with their evaluated electrophilicity index is depicted in the Figure 2. The high value of regression coefficient $\left(R^{2}=0.902\right)$ supports our prediction.

The shell model of metal clusters arises on the concept of full delocalization of molecular orbitals for the cluster electrons, in which the valence electrons of the cluster atoms are placed in shells of $s, p$ and $d$ character of the overall system. ${ }^{72-75}$ The analysis of the $(\mathrm{CuS})_{3}$ clusters in terms of orbitals i.e., HOMO, HOMO-1, LUMO and LUMO+1, exhibiting the highest HOMO-LUMO gap among the mentioned nano-clusters, is plotted in the Figure 3 .

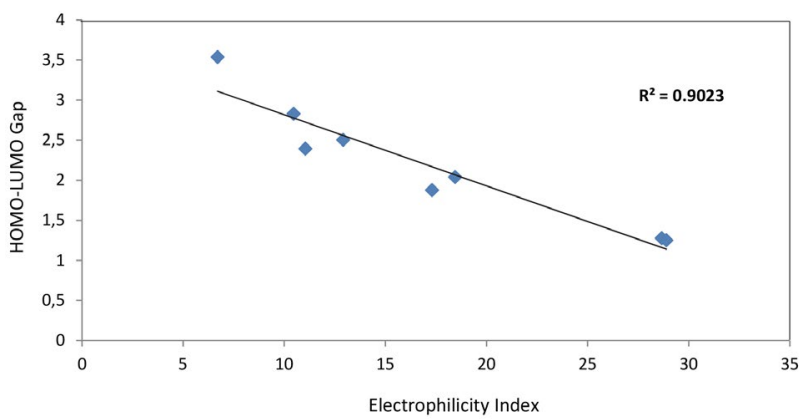

Figure 2. A Correlation Plot between Electrophilicity Index $(e V)$ Vs HOMO-LUMO Gap (eV)

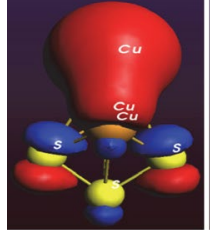

НОМО

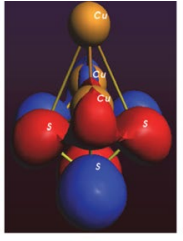

HOMO-1

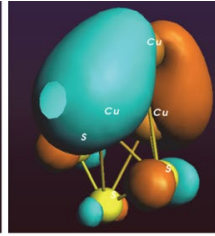

LUMO

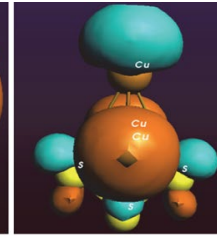

LUMO+1
Figure 3. Orbitals of $(\mathrm{CuS})_{3}$ Nanoalloy Cluster

A comparative analysis has also been done in the Table-2, between experimental bond length and frequency with our computed data of the species namely $\mathrm{Cu}_{2}, \mathrm{~S}_{2}$ and $\mathrm{CuS}$. The result reveals that bond lengths follow the order as- $\mathrm{Cu}-\mathrm{Cu}>\mathrm{Cu}-\mathrm{S}>\mathrm{S}-\mathrm{S}$, which is in same line as previously reported. ${ }^{15}$ The close agreement between the experiment data and our computed data signifies the theoretical analysis.

\section{Conclusion}

Study on copper-sulfide nanoalloy clusters has become important considering its wide field applications. In this paper, computational analysis of the structure, electronic and optical/ photo-catalytic properties of $(\mathrm{CuS})_{\mathrm{n}},[\mathrm{n}$ $=1-8]$ nanoalloy clusters in terms of conceptual DFT based descriptors, are reported. The ground state configurations and low-lying isomers of $(\mathrm{CuS})_{\mathrm{n}}$ clusters have been analyzed invoking electronic structure theory. The result exhibits an appearance of $3 \mathrm{D}$ structure of $(\mathrm{CuS})_{3}$ with $\mathrm{C}_{1}$

Table 1. Computed DFT Based Global Descriptors of $(\mathrm{CuS})_{\mathrm{n}}$ nanoalloy clusters $(\mathrm{n}=1-8)$

\begin{tabular}{|c|c|c|c|c|c|c|}
\hline Species & $\begin{array}{c}\text { HOMO- } \\
\text { LUMO Gap }(\mathrm{eV})\end{array}$ & $\begin{array}{l}\text { Electronegativity } \\
(\mathrm{eV})\end{array}$ & $\begin{array}{c}\text { Global } \\
\text { Hardness }(\mathrm{eV})\end{array}$ & $\begin{array}{c}\text { Global } \\
\text { Softness }(\mathrm{eV})\end{array}$ & $\begin{array}{l}\text { Electrophilicity } \\
\text { Index }(e V)\end{array}$ & $\begin{array}{c}\text { Dipole } \\
\text { Moment (Debye) }\end{array}$ \\
\hline $\mathrm{CuS}$ & 2.394 & 5.142 & 1.197 & 0.417 & 11.045 & 4.440 \\
\hline$(\mathrm{CuS})_{2}$ & 1.278 & 6.054 & 0.639 & 0.781 & 28.661 & 0.658 \\
\hline$(\mathrm{CuS})_{3}$ & 3.537 & 4.870 & 1.768 & 0.282 & 6.706 & 0.817 \\
\hline$(\mathrm{CuS})_{4}$ & 1.251 & 6.013 & 0.625 & 0.798 & 28.890 & 3.986 \\
\hline$(\mathrm{CuS})_{5}$ & 2.041 & 6.135 & 1.020 & 0.490 & 18.448 & 1.533 \\
\hline$(\mathrm{CuS})_{6}$ & 1.877 & 5.701 & 0.938 & 0.532 & 17.308 & 4.814 \\
\hline$(\mathrm{CuS})_{7}$ & 2.829 & 5.442 & 1.414 & 0.353 & 10.465 & 2.142 \\
\hline$(\mathrm{CuS})_{8}$ & 2.503 & 5.686 & 1.251 & 0.399 & 12.910 & 1.744 \\
\hline
\end{tabular}

Table 2. A comparative analysis between computed bond lengths $(\AA)$ and frequency $\left(\mathrm{cm}^{-1}\right)$ with their experimental counterparts for the species $\mathrm{Cu}_{2}, \mathrm{~S}_{2}$ and $\mathrm{CuS}^{76-79}$

\begin{tabular}{|c|c|c|c|c|}
\hline \multirow[t]{2}{*}{ Species } & \multirow{2}{*}{$\begin{array}{l}\text { Computed } \\
\text { bond length }\end{array}$} & \multirow{2}{*}{$\begin{array}{l}\text { Experimental } \\
\text { bond length }\end{array}$} & \multicolumn{2}{|c|}{ Computed Experimental } \\
\hline & & & Frequency & Frequency \\
\hline $\mathrm{Cu}_{2}$ & 2.25 & 2.21 & 257 & 265 \\
\hline $\mathrm{S}_{2}$ & 2.07 & 1.89 & 662 & 726 \\
\hline $\mathrm{CuS}$ & 2.18 & 2.05 & 372 & 415 \\
\hline
\end{tabular}

symmetry, which is more stable than the planar structure. The computed HOMO-LUMO gap, ranging from 1.25 to $3.53 \mathrm{eV}$, makes these clusters as potential candidates for renewable energy sources. Our computational data identifies the most reactive and least reactive species. The computed data describes that optical property of the instant clusters and global hardness run hand in hand, which is very much expected considering experimental facts. The high value of regression coefficient between electrophilici- 
ty index and HOMO-LUMO gap supports our predicted model. Observed close agreement between experimental bond length and frequency with our computed data encourages further possibility of analysis in this domain.

\section{References}

1. J. Kundu, D. Pradhan, New J. Chem. 2013, 37, 1470-1478. DOI:10.1039/c3nj41142g

2. M. Antoniadou, V. M. Daskalaki, N. Balis, D. I. Kondarides, C. Kordulis, P. Lianos, Appl. Catal. B 2011, 107, 188-196. DOI:10.1016/j.apcatb.2011.07.013

3. C. H. Lai, M. Y. Lu, L. J. Chen, J. Mater. Chem. 2012, 22, 19-30. DOI:10.7312/li--16274-023

4. M. G. Panthani, V. Akhavan, B. Goodfellow, J. P. Schmidtke, L. Dunn, A. Dodabalapur, P. F. Barbara, B. A. Korgel, J. Am. Chem. Soc. 2008, 130, 16770-16777.

DOI: $10.1021 / \mathrm{ja} 805845 \mathrm{q}$

5. J. S. Steckel, J. P. Zimmoler, S. C.-Sullivan, N. E. Stott, V. Bulovic, M. G. Bawendi, Angew. Chem., Int. Ed. 2004, 43, 2154-2158. DOI:10.1002/anie.200453728

6. Y. Justo, B. Goris, J. S. kamal, P. Geiregat, S. Bals, Z. Hens, J. Am. Chem. Soc. 2012, 134, 5484-5487.

DOI:10.1021/ja300337d

7. Y. Zhao, C. Burda, Energy Environ. Sci. 2012, 5, 5564-5576. DOI:10.1039/C1EE02734D

8. A. A. Sagade, R. Sharma, I. Sulaniya, J. Appl. Phys. 2009, 105, 043701-1-8. DOI:10.1063/1.3053350

9. T. Sakamoto, H. Sunamura, H. Kawuara, T. Hasegawa, T. Nakayama, M. Aono, Appl. Phys. Lett. 2003, 82, 3032-3034. DOI:10.1063/1.1572964

10. E. Ramli, T. B. Rauchfuss, C. L. Stern, J. Am. Chem. Soc. 1990, 112, 4043-4044. DOI:10.1021/ja00166a054

11. L. Reijnen, B. Meester, A. Goossens, J. Schoonman, Chem. Vap. Deposition 2003, 9, 15-20.

DOI:10.1002/cvde.200290001

12. M. C. Lin, M. W. Lee, Electrochem. Commun. 2011, 13, 1376-1378. DOI:10.1016/j.elecom.2011.08.013

13. Y. Wu, C. Wadia, W. Ma, B. Sadtler, A. P. Alivisatos, Nano Lett. 2008, 8, 2551-2555.

DOI: $10.1021 / \mathrm{nl} 801817 \mathrm{~d}$

14. T. Rasmussen, B. C. Berks, J. S. Loehr, D. M. Dooley, W. G. Zumft, A. J. Thomson, Biochemistry 2000, 39, 12753-12756. DOI:10.1021/bi001811i

15. O. J. J.-Sanchez, N. P. -Peralta, R. H. - Urbina, M. Sanchez, A. P. -Amarillas Chem. Phys. Lett. 2013, 570, 132-135.

16. R. Ferrando, J. Jellinek, R. L. Johnston, Chem. Rev. 2008, 108, 845-910. DOI:10.1021/cr040090g

17. N. Sounderya, Y. Zhang, Recent Pat. Biomed. Eng. 2008, 1, 34-42. DOI:10.2174/1874764710801010034

18. O. V. J. Salata, Nanobiotechnology 2004, 2, 3-10. DOI:10.1186/1477-3155-2-3

19. W. He, X. Wu, J. Liu, X. Hu, K. Zhang, S. Hou, W. Zhou, S. Xie, Chem. Mater. 2010, 22, 2988-2994.

DOI:10.1021/cm100393v
20. H. -J. Freund, Surf. Sci. 2002, 500, 271-299. DOI:10.1016/S0039-6028(01)01543-6

21. J. K. Norskov, T. Bligaard, J. Rossmaisi, C. H. Christensen, Nat. Chem. 2009, 1, 37-46. DOI:10.1038/nchem.121

22. A. Henglein, J. Phys. Chem. 1993, 97, 5457-5471. DOI:10.1021/j100123a004

23. S. C. Davis, K. J. Klabunde, Chem. Rev. 1982, 82, 153-208. DOI: $10.1021 / \mathrm{cr} 00048 \mathrm{a} 002$

24. L. N. Lewis, Chem. Rev. 1993, 93, 2693-2730. DOI:10.1021/cr00024a006

25. H. Y. Oderji, H. Ding, Chem. Phys. 2011, 388, 23-30. DOI:10.1016/j.chemphys.2011.07.011

26. F. Baletto, R. Ferrando, Rev. Mod. Phys. 2005, 77, 371-423. DOI:10.1103/RevModPhys.77.371

27. R. Koole, E. Groeneveld, D. Vanmaekelbergh, A. Meijerink, C. D. M. Dongea, in: C. D. M. Dongea (Ed.): Nanoparticles: Workhorses of Nanoscience, Springer-Verlag Berlin Heidelberg, 2014, pp. 13-51.

28. K. Hashimoto, H. Irie, A. Fujishima, Jpn. J. Appl. Phys. 2005, 44, 8269-8285. DOI:10.1143/JJAP.44.8269

29. A. Fujishima, K. Honda, Nature 1972, 238, 37-38. DOI:10.1038/238037a0

30. A. Kudo, Pure Appl. Chem. 2007, 79, 1917-1927. DOI:10.1351/pac200779111917

31. N. V. Long, T. D. Hien, T. Asaka, M. Ohtaki, M. Nogami, Int. J. Hydrogen Energy 2011, 36, 8478-8491.

DOI:10.1016/j.ijhydene.2011.03.140

32. M. Page, O. Niitsoo, Y. Itzhaik, D. Cahen and G. Hodes, Energy Environ. Sci. 2009, 2, 220-223.

DOI:10.1039/B813740D

33. Y. Zhao, H. Pan, Y. Lou, X. Qiu, J. Zhu, C. Burda, J. Am. Chem. Soc. 2009, 131, 4253-4261. DOI:10.1021/ja805655b

34. P. V. Q.-Ramirez, M. C. A. Arrocena, J. S. Cruz, M. V. Gonzalez, O. M. Alvarez, V. M. C. Meneses, L. S. A. Torres, Beilstein J. Nanotechnol. 2014, 5, 1542-1552.

35. P. Leidinger, R. Popescu, D. Gerthsen, H. Lunsdorf, C. Feldmann, Nanoscale 2011, 3, 2544-2551.

DOI:10.1039/clnr10076a

36. M. T. S. Nair, L. Guerrero, P. K. Nair, Semicond. Sci. Technol. 1998, 13, 1164-1169. DOI:10.1088/0268-1242/13/10/019

37. I. Grozdanov, M. Najdoski, Solid State Chem. 1995, 114, 469-475. DOI:10.1006/jssc.1995.1070

38. L. Chen, Y. D. Xia, X. F. Liang, K. B. Yin, J. Yin, Z. G. Liu, Y. Chen, Appl. Phys. Lett. 2007, 91, 073511-073513. DOI: $10.1063 / 1.2771064$

39. C. -G. Li, Y. -Q. Yuan, Y.-F. Hu, J. Zhang, Y.-N. Tang, B. -Z. Ren, Comput. Theor. Chem. 2016, 1080, 47-55. DOI:10.1016/j.comptc.2016.01.018

40. K. Sun, D. Su, Q. Zhang, D. C. Bock, A. C. Marschilok, K. J. Takeuchi, E. S. Takeuchi, H. Gan, J. Electrochem. Soc. 2015, 162, A2834-A2839. DOI:10.1149/2.1021514jes

41. G. Chen, Z. Wei, B. Jin, X. Zhong, H. Wang, W. Zhang, J. Liang, Q. Jiang, Appl. Surf. Sci. 2013, 277, 268-271. DOI:10.1016/j.apsusc.2013.04.041

42. M. Nagarathinam, K. Saravanan, W. L. Leong, P. Balaya, J. J. Vittal, Cryst. Growth Des. 2009, 9, 4461-4470. 


\section{DOI:10.1021/cg9004938}

43. Y. Wang, X. Zhang, P. Chen, H. Liao, S. Cheng, Electrochim. Acta. 2012, 80, 264-268.

DOI:10.1016/j.electacta.2012.07.004

44. Y. Du, Z. Yin, J. Zhu, X. Huang, X. J. Wu, Z. Zeng, Q. Yan, H. Zhang, Nat. Commun. 2012, 3, 1177-1183.

DOI:10.1038/ncomms2181

45. S. Zheng, Y. Feng, Z. Li, Y. Zhu, Y. Xu, C. Luo, J. Yang, C. Wang, Adv. Funct. Mater. 2014, 24, 4156-4263.

DOI:10.1002/adfm.201304156

46. Y. Xie, G. Bertoni, A. Riedinger, A. Sathya, M. Prato, S. Marras, R. Tu, T. Pellegrino, L. Manna, Chem. Mater. 2015, 27, 7531-7537. DOI:10.1021/acs.chemmater.5b03892

47. N. Karikalan, R. Karthik, S. M. Chen, C. Karuppiah, A. Elangovan, Sci. Rep. 2017, 7, 2494-2504.

DOI:10.1038/s41598-017-02479-5

48. S. S. T. Selvi, J. M. Linet, S. Sagadevan, J. Exp. Nanosci. 2018, 13, 130-143. DOI:10.1080/17458080.2018.1445306

49. C. Ratanatawanate, A. Bui, K. Vu, K. J. Balkus, J. Phys. Chem. C 2011, 115, 6175-6180. DOI:10.1021/jp109716q

50. J. Zhang, J. Yu, Y. Zhang, Q. Li, J. R. Gong, Nano Lett. 2011, 11, 4774-4779. DOI:10.1021/nl202587b

51. O. J. Wacker, R. Kummel, E. K. U. Gross, Phys. Rev. Lett.1994, 73, 2915-2918. DOI:10.1103/PhysRevLett.73.2915

52. B. Gyorffy, J. Staunton, G. Stocks in: E. Gross, R. Dreizler (Eds.), Fluctuations in density functional theory: random metallic alloys and itinerant paramagnets, Plenum, NY, 1995, pp. 461-484. DOI:10.1007/978-1-4757-9975-0_18

53. R. Car, M. Parrinello, Phys. Rev. Lett. 1985, 55, 2471-2474. DOI:10.1103/PhysRevLett.55.2471

54. M. Koskinen, P. Lipas, M. Manninen, Nucl. Phys. A 1995, 591, 421-434. DOI:10.1016/0375-9474(95)00209-J

55. R. G. Parr, W. Yang, Annu. Rev. Phy. Chem. 1995, 46, 701-728. DOI:10.1146/annurev.pc.46.100195.003413

56. W. Kohn, A. D. Becke, R. G. Parr, J. Phys. Chem. 1996, 100, 12974-12980. DOI:10.1021/jp9606691

57. T. Ziegler, Chem.Rev. 1991, 91, 651-667. DOI:10.1021/cr00005a001

58. R. G. Parr, W. Yang, Density functional theory of atoms and molecules, Oxford, University Press, Oxford, 1989.

59. H. Chermette, J. Comput. Chem. 1999, 20, 129-154. DOI:10.1002/(SICI)1096-987X(19990115)20:1<129::AIDJCC13>3.0.CO;2-A

60. P. Geerlings, F. D. Proft, W. Langenaeker, Chem. Rev. Washington, D.C. 2003, 103, 1793-1874.

61. P. Geerlings, F. D. Proft, Int. J. Mol. Sci. 2002, 3, 276-309. DOI: $10.3390 / \mathrm{i} 3040276$

62. P. Ranjan, A. Kumar, T. Chakraborty, in: G. M. Mishra(Ed.), Environmental Sustainability: Concepts, Principles, Evidences and Innovations, Excellent Publishing House, New Delhi, , 2014, pp. 239-242.

63. P. Ranjan, S. Venigalla, A. Kumar, T. Chakraborty, in: T. Chakraborty, L. Ledwani (Eds.), Research Methodology in Chemical Sciences: Experimental and Theoretical Approaches, Apple Academic Press, USA, 2016, pp. 337-346.

DOI:10.1201/b19855-19
64. P. Ranjan, S. Dhail, S. Venigalla, A. Kumar, L. Ledwani, T. Chakraborty, Mat. Sci.- Pol. 2015, 33, 719-724.

DOI:10.1515/msp-2015-0121

65. P. Ranjan, S. Venigalla, A. Kumar, T. Chakraborty, New Front. Chem. 2014, 23, 111-122.

66. S. Venigalla, S. Dhail, P. Ranjan, S. Jain, T. Chakraborty, New Front. Chem. 2014, 23, 123-130.

67. P. Ranjan, A. Kumar, T. Chakraborty, AIP Conf. Proc. 2016, 1724, 020072.

68. P. Ranjan, A. Kumar, T. Chakraborty, Mat. Today Proc. 2016, 3, 1563-1568. DOI:10.1016/j.matpr.2016.04.043

69. Gaussian 03, Revision C.02, M. J. Frisch, G. W. Trucks, H. B. Schlegel, G. E. Scuseria, M. A. Robb, J. R. Cheeseman, J. A. Montgomery, Jr., T. Vreven, K. N. Kudin, J. C. Burant, J. M. Millam, S. S. Iyengar, J. Tomasi, V. Barone, B. Mennucci, M. Cossi, G. Scalmani, N. Rega, G. A. Petersson, H. Nakatsuji, M. Hada, M. Ehara, K. Toyota, R. Fukuda, J. Hasegawa, M. Ishida, T. Nakajima, Y. Honda, O. Kitao, H. Nakai, M. Klene, X. Li, J. E. Knox, H. P. Hratchian, J. B. Cross, V. Bakken, C. Adamo, J. Jaramillo, R. Gomperts, R. E. Stratmann, O. Yazyev, A. J. Austin, R. Cammi, C. Pomelli, J. W. Ochterski, P. Y. Ayala, K. Morokuma, G. A. Voth, P. Salvador, J. J. Dannenberg, V. G. Zakrzewski, S. Dapprich, A. D. Daniels, M. C. Strain, O. Farkas, D. K. Malick, A. D. Rabuck, K. Raghavachari, J. B. Foresman, J. V. Ortiz, Q. Cui, A. G. Baboul, S. Clifford, J. Cioslowski, B. B. Stefanov, G. Liu, A. Liashenko, P. Piskorz, I. Komaromi, R. L. Martin, D. J. Fox, T. Keith, M. A. Al-Laham, C. Y. Peng, A. Nanayakkara, M. Challacombe, P. M. W. Gill, B. Johnson, W. Chen, M. W. Wong, C. Gonzalez, and J. A. Pople, Gaussian, Inc., Wallingford CT, 2004.

70. H. Xiao, J. T. Kheli, W. A. Goddard III, J. Phys. Chem. Lett. 2011, 2, 212-217. DOI:10.1021/jz101565j

71. R. G. Parr, L. V. Szentpaly, S. Liu, J. Am. Chem. Soc. 1999, 121, 1922-1924. DOI:10.1021/ja983494x

72. W. A. deHeer, Rev. Mod. Phys. 1993, 65, 611-676.

DOI:10.1103/RevModPhys.65.611

73. W. D. Knight, K. Clemenger, W. A. deHeer, M. Y. Chou, M. L. Cohen, Phys. Rev. Lett. 1984, 52, 2141-2143.

DOI:10.1103/PhysRevLett.52.2141

74. W. Ekardt, Z. Penzar, Phys. Rev. B. 1998, 38, 4273-4276. DOI:10.1103/PhysRevB.38.4273

75. M. L. Cohen, W. D. Knight, Phys. Today. 1990, 43, 42-50. DOI: $10.1063 / 1.881220$

76. R. P. Amerigo, M. Merchan, I. N. Gil, P. A. Malmqvist, B. O. Roos, J. Chem. Phys. 1994, 101, 4893-4902.

DOI:10.1063/1.467411

77. H. E. King Jr., C. T. Prewitt, Am. Mineral. 1979, 64, 12651271.

78. H. W. Evans Jr., Am. Mineral. 1981, 66, 807-810.

79. D. Hohl, R. O. Jones, R. Car, M. Parrinello, J. Chem. Phys. 1988, 89, 6823-6835. DOI:10.1063/1.455356 


\section{Povzetek}

Nanoklastri bakrovih sulfidov $(\mathrm{CuS})$ so zaradi njihovih adsorpcijskih lastnosti in netoksičnosti izjemnega pomena. V prispevku smo nanoklastre $(\mathrm{CuS})_{\mathrm{n}}(\mathrm{n}=1-8)$ analizirali s pomočjo računske kemije na podlagi teorije gostotnega potenciala (conceptual DFT (CDFT)), z namenom dobiti vpogled v njihove elektronske in druge lastnosti. S pomočjo DFT kalkulacij smo izračunali nekatere parametre (»global descriptors«) za konfiguracije osnovnega stanja in nizko ležeče izomere $(\mathrm{CuS})_{n}$ klastrov. Izračunane HOMO-LUMO vrzeli, ki ležijo v območju od 1,25 do 3,53 eV kažejo, da bi lahko $(\mathrm{CuS})_{\mathrm{n}}$ klastre uporabljali v procesu pridobivanja energije iz obnovljivih virov, zlasti pri fotokatalizi in kot material $\mathrm{v}$ sončnih celicah. Prikazali smo statistično korelacijo med elektronskimi in fotokatalitičnimi lastnostmi nanoklastrov na osnovi bakrovih sulfidov. Takšen pristop računske kemije podpira tudi ujemanje med eksperimentalnimi in izračunanimi podatki. 